\title{
PHACE syndrome in a preterm infant
}

Sylke J. Steggerda, MD, PhD, Ratna N.G.B. Tan, MD, and Peter C.J. de Laat, MD, PhD

Neurology ${ }^{\circledR}$ 2020;95:751-752. doi:10.1212/WNL.0000000000010800

\section{Correspondence}

Dr. Steggerda

s.j.steggerda@lumc.nl

Figure 1 Evolution of facial hemangioma in a preterm infant with PHACE syndrome

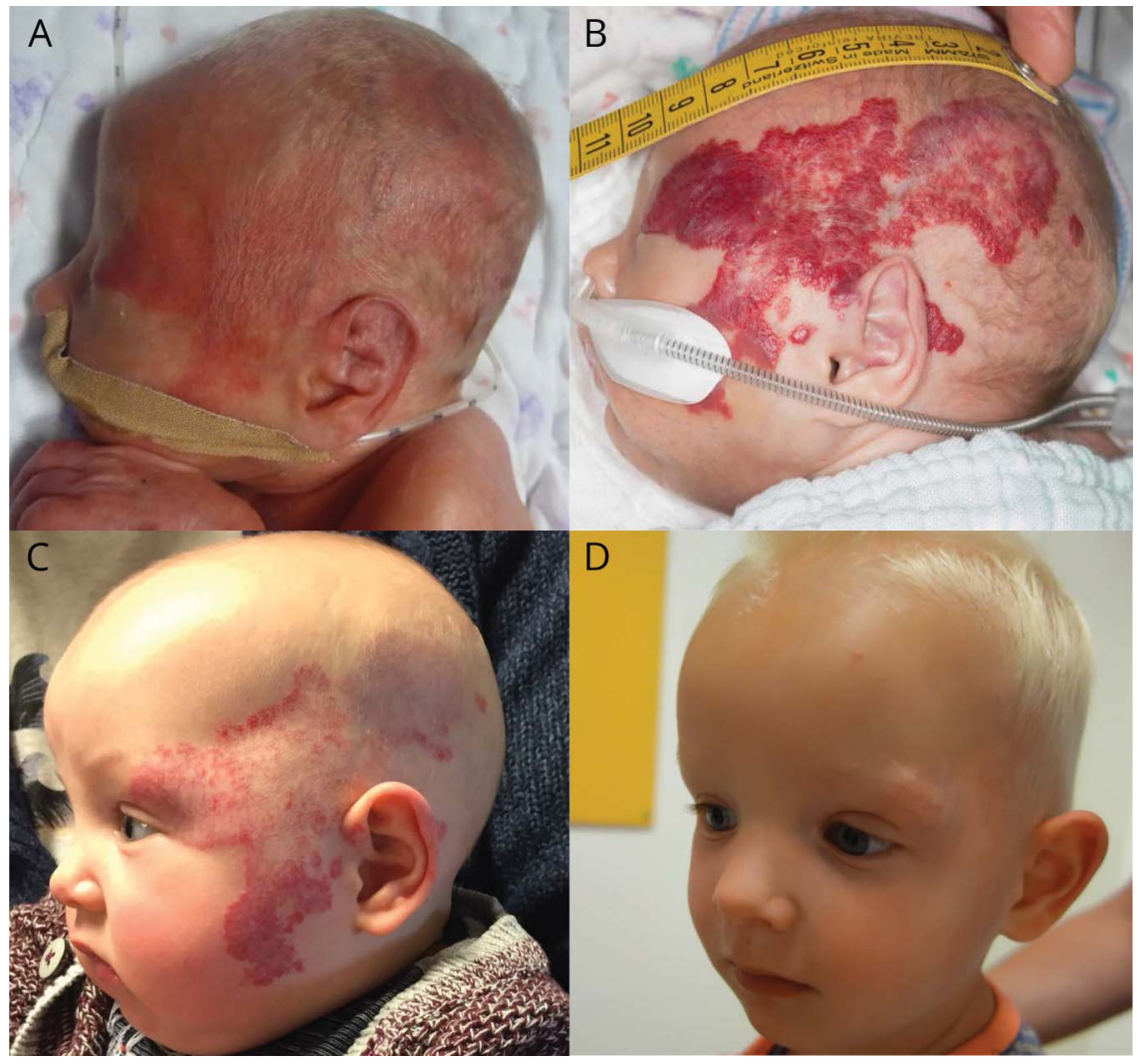

(A) At day 5, erythematous lesion in left frontotemporal segment; (B) at 2 weeks; (C, D) at 6 months and 2 years.

In a preterm infant (28 weeks), postnatal cranial ultrasound showed unilateral cerebellar hypoplasia. On day 5, a facial erythematous lesion developed, progressing to a segmental hemangioma during the next 2 weeks (figure 1, A and B). PHACE syndrome (posterior fossa anomalies, most commonly located in the mid brain or hindbrain, such as the Dandy-Walker complex and focal dysplasia and/or hypoplasia of the cerebellum, hemangioma, arterial lesions, cardiac abnormalities or coarctation of the aorta, eye or endocrine abnormalities) ${ }^{1}$ was suspected. MRI confirmed cerebellar hypoplasia and intracranial hemangioma (figure 2). Magnetic resonance angiography and echocardiogram were normal. Because of obstruction of the visual axis, low-dose atenolol was started $(0.5-1.0 \mathrm{mg} / \mathrm{kg} / \mathrm{d})$, and continued for 2 years.

Regression of the hemangioma started within the first week of treatment (figure 1, C and D). MRI at 1.5 years showed complete resolution of intracranial hemangioma. Neurodevelopment and ophthalmologic outcome at 2 years were normal. The child developed bilateral conductive hearing loss.

From the Department of Paediatrics (S.J.S., R.N.G.B.T.), Division of Neonatology, Leiden University Medical Centre; and Department of Paediatrics (P.C.J.d.L.), Vascular Anomaly Center, Erasmus Medical Centre, Rotterdam, the Netherlands.

Go to Neurology.org/N for full disclosures. Funding information and disclosures deemed relevant by the authors, if any, are provided at the end of the article. 
Figure 2 Ultrasound and MRI of the brain in a preterm infant with PHACE syndrome

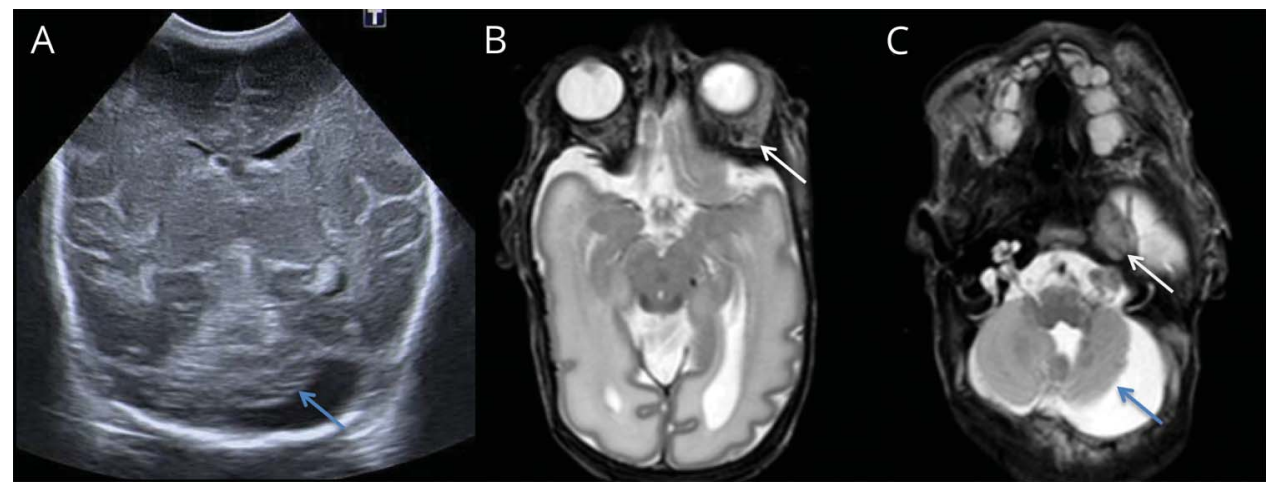

Postnatal ultrasound (A) and MRI at 31 weeks $(B, C)$ show unilateral cerebellar hypoplasia (blue arrows) and ipsilateral periorbital and cerebellopontine angle hemangioma (white arrows).

\section{Study funding}

No targeted funding reported.

\section{Disclosures}

The authors report no disclosures relevant to the manuscript. Go to Neurology.org/N for full disclosures.

\section{Appendix Authors}

\begin{tabular}{|c|c|c|}
\hline Name & Location & Contribution \\
\hline $\begin{array}{l}\text { Sylke J. } \\
\text { Steggerda, } \\
\text { MD, PhD }\end{array}$ & $\begin{array}{l}\text { Department of Paediatrics, } \\
\text { Division of Neonatology, } \\
\text { Leiden University Medical } \\
\text { Centre, the Netherlands }\end{array}$ & $\begin{array}{l}\text { Study concept and design, } \\
\text { acquisition of data, } \\
\text { neuroimaging, drafted and } \\
\text { revised the manuscript }\end{array}$ \\
\hline
\end{tabular}

Appendix (continued)

\begin{tabular}{lll}
\hline Name & Location & Contribution \\
\hline $\begin{array}{l}\text { Ratna } \\
\text { N.G.B. Tan, } \\
\text { MD }\end{array}$ & $\begin{array}{l}\text { Department of Paediatrics, } \\
\text { Division of Neonatology, } \\
\text { Leiden University Medical } \\
\text { Centre, the Netherlands }\end{array}$ & $\begin{array}{l}\text { Study concept and design, } \\
\text { acquisition of data, } \\
\text { neuroimaging, drafted and } \\
\text { revised the manuscript }\end{array}$ \\
\hline $\begin{array}{l}\text { Peter C.J. } \\
\text { de Laat, } \\
\text { MD, PhD }\end{array}$ & $\begin{array}{ll}\text { Department of Paediatrics, } \\
\text { Vascular Anomaly Center, }\end{array}$ & $\begin{array}{l}\text { Study concept and design, } \\
\text { acquisition of data, } \\
\text { Eeuroimaging, drafted and } \\
\text { Revised the manuscript }\end{array}$ \\
& $\begin{array}{l}\text { Rotterdam, the } \\
\text { Netherlands }\end{array}$ & \\
\hline
\end{tabular}

\section{Reference}

1. Garzon MC, Epstein LG, Heyer GL, et al. PHACE syndrome: consensus-derived diagnosis and care recommendations. J Pediatr 2016;178:24-33.

\section{Visit the Neurology ${ }^{\circledR}$ Website at Neurology.org/N}

- More article-based content on home pages

- Streamlined menus and navigation

- Enhanced blog sections for specialty areas

- Same experience on desktop, tablet, and mobile devices

- Improved article reading experience; links more evident (pdf, analytics, social media)

- Neurology ${ }^{\circledR}$ Clinical Practice initiative "Practice Current" global surveys will be accessible across sites

f Find Neurology ${ }^{\circledR}$ on Facebook: http://tinyurl.com/neurologyfan

Follow Neurology ${ }^{\circledR}$ on Twitter: https://twitter.com/GreenJournal 


\title{
Neurology
}

\author{
PHACE syndrome in a preterm infant \\ Sylke J. Steggerda, Ratna N.G.B. Tan and Peter C.J. de Laat \\ Neurology 2020;95;751-752 Published Online before print September 10, 2020 \\ DOI 10.1212/WNL.0000000000010800
}

This information is current as of September 10, 2020

\begin{tabular}{|c|c|}
\hline $\begin{array}{l}\text { Updated Information \& } \\
\text { Services }\end{array}$ & $\begin{array}{l}\text { including high resolution figures, can be found at: } \\
\text { http://n.neurology.org/content/95/16/751.full }\end{array}$ \\
\hline References & $\begin{array}{l}\text { This article cites } 1 \text { articles, } 0 \text { of which you can access for free at: } \\
\text { http://n.neurology.org/content/95/16/751. full\#ref-list- } 1\end{array}$ \\
\hline Subspecialty Collections & $\begin{array}{l}\text { This article, along with others on similar topics, appears in the } \\
\text { following collection(s): } \\
\text { All Neuro-ophthalmology } \\
\text { http://n.neurology.org/cgi/collection/all_neuroophthalmology } \\
\text { MRI } \\
\text { http://n.neurology.org/cgi/collection/mri } \\
\text { Neonatal } \\
\text { http://n.neurology.org/cgi/collection/neonatal } \\
\text { Pediatric stroke; see Cerebrovascular Disease/Childhood stroke } \\
\text { http://n.neurology.org/cgi/collection/pediatric_stroke_see_cerebrovascu } \\
\text { lar_disease-childhood_stroke }\end{array}$ \\
\hline Permissions \& Licensing & $\begin{array}{l}\text { Information about reproducing this article in parts (figures,tables) or in } \\
\text { its entirety can be found online at: } \\
\text { http://www.neurology.org/about/about_the_journal\#permissions }\end{array}$ \\
\hline Reprints & $\begin{array}{l}\text { Information about ordering reprints can be found online: } \\
\text { http://n.neurology.org/subscribers/advertise }\end{array}$ \\
\hline
\end{tabular}

Neurology ${ }^{\circledR}$ is the official journal of the American Academy of Neurology. Published continuously since 1951, it is now a weekly with 48 issues per year. Copyright @ 2020 American Academy of Neurology. All rights reserved. Print ISSN: 0028-3878. Online ISSN: 1526-632X.

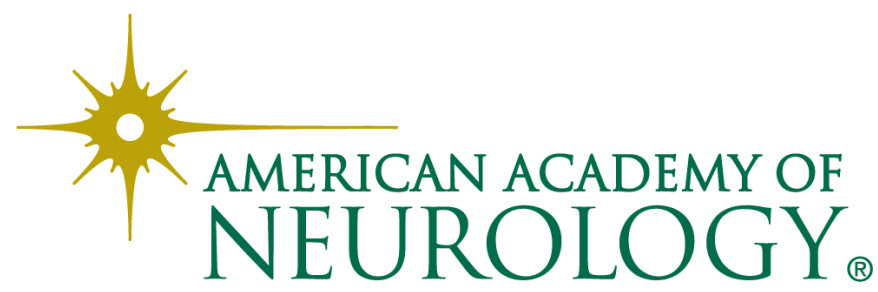

